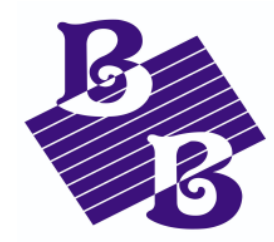

BioBacta

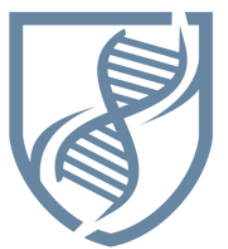

Journal of Bioscience and Applied Research

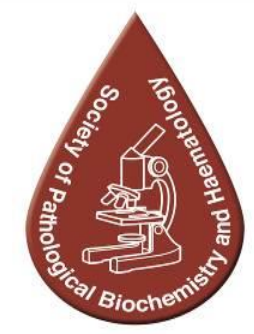

www.jbaar.org

\title{
Study effect of Sunlight on the chemical composition of Milk
}

\section{Qaswaa Yousif Jameel}

Food science Department, colleges of Agricultural and Forestry - Mosul University, Mosul, Iraq

\author{
E-mail: dr.qaswaa_yousif@uomosul.edu.iq
}

Received: March 17, 2020. Accepted: September 5, 2020. Published: September 25, 2020

DOI: $10.21608 /$ jbaar.2020.118765

\begin{abstract}
:
Light-induced degradation reactions make a serious problem for the milk because of the development of flavors and a decrease in nutritional quality, materials of Packaging are important to avoid this particular degradation of milk. In this study, were divided milk into two groups (light exposed ) + (light protected (foil overwrap)) under the same cooling conditions at $3{ }^{\circ} \mathrm{C}$ for 15 days, those expectant during the show in stores of retail and markets. And the effect of this on the chemical composition of milk, the results of my study then showed that the appropriate blocking light with an overwrap of foil helped inhibit lipid and protein Lipolysis compared with the samples exposed to light under the same cooling conditions. Therefore, the appropriate Blocking of visible light with foil overwrap can increase milk's shelf life.
\end{abstract}

Keyword: whole Milk, foil, light exposed, high-density polyethylene

\section{Introduction:}

Milk is a nutritional material of high nutrient content, it is an ideal medium for the growth of every class of human beings and It is also an ideal medium for the growth and multiplication of diverse microorganisms[1]. Consumed milk largely for high nutritional value but limited shelf life, as it cannot keep up quality for more than (2 - 3) days [2]. Milk and milk products are susceptible to lightinduced oxidation reactions, which can negatively affect odor and flavor Photooxidation of milk occurs under the presence of light (artificial, sunlight)[3], is an indicating of degradation of milk during transportation[4]. Exposure of milk to light facilitates the degradation of amino acids and vitamin A, and fat oxidation [5]. Packaging materials are important to prevent this deterioration of milk [6], for this reason, packaging of dairy products to protect from light and give it a long shelf life [7]. Can be used specially designed packaging [8], to reduced light oxidation flavor [9], reducing material permeability and negative sensory characteristics for extending the shelf life better [10], That exposure to fluorescent light in stores becomes a significant problem[11]. The milk stored in bottles photo-oxidation experienced and lost vitamin[12]. Moreover, conveying milk products from the store to home in transparent containers[13]. Therefore, this study investigates the use of packaging that blocks detrimental light 
wavelengths blocking visible light with labels to inhibit lipid oxidation and to evaluate its stability during storage.

\section{Material and Methods}

\subsection{Experimental}

In this study, whole milk was used by the Iranian company Kallah milk packaged in highdensity polyethylene (HDPE) Bottle dimensions were 7.16 " height $\times 3.29$ " width $\times$ 2.1 " depth and a volume of $528 \mathrm{ml}$. The samples were divided into two groups (light exposed ) + ( light protected (foil overwrap)) under the same cooling conditions at $3^{\circ} \mathrm{C}$ [12] for 15 days [15]. The samples were divided into 11 groups each of which contained 5 replicates, and as follows:

T0: Standard samples stored for 0 days.

T1: samples stored for 3 days (light protected),

T2: samples stored for 3 days (light-exposed).

T3: samples stored for 6 days (light protected), T4: samples stored for 6 days (light-exposed).

T5: samples stored for 9 days (light protected), T6: samples stored for 9 days (light-exposed).

T7: samples stored for 12 days (light protected), T8: samples stored for 12 days (light-exposed).

T9: samples stored for 15 days (light protected), T10: samples stored for 15 days (light-exposed).

\subsection{Chemical Analysis}

\subsubsection{Determination of Fat}

The fat content was measured using the Gerber method [16].

\subsubsection{Determination of Total Protein and}

\section{Casein}

Total Protein content and Casein of milk were assessed utilizing the modified method of Castillo et al,[17] .

\subsubsection{Determination of Lipolysis}

Lipolysis was calculated as acid degree value, acid value, and free fatty acid, according to the reported procedure given by [18].

\subsection{Statistical Analysis}

The experimental results were analyzed statistically, using the SAS program. In addition, multiple range testing of Duncan's correlation coefficient was used to compare results between the various parameters. Statistical analysis is described as mean \pm standard deviation, and is found to be statistically significant at $\mathrm{p}<.05$.

\section{Results and discussion \\ 3.1. Total protein $\&$ casein:}

Total protein and casein concentrations had decreased in all formulas. The differences in Total protein and casein were due to The proteolytic activities in milk, including proteolytic enzymes from proteolytic systems, which can be functionally divided into cell-surface-associated proteinases that hydrolyze caseins to oligopeptides, and peptide transport systems that transport the oligopeptide and numerous intracellular peptidases [19]. The average initial Total protein concentration in milk for this study $(2.99667 \%)$, casein $(2.58333 \%)$ for both replications; all protein and casein concentrations values throughout the study were at that level or decreased with time and light exposure. protein degradation is undesirable in food systems because it decreases the nutritional value of the food protein and casein concentration in milk decreased over the 15 days of evaluation in all packages [Table 1]. protein and casein in milk from the light-protected treatment did not change significantly $(\mathrm{P}>0.05)$, compared with the exposure to light through d 15, protein and casein concentration in milk in the light protected package was significantly higher $(<0.05)$ than in light exposed package due to light exposure.The reason for the differences in the protein ratios between the treatments to the destruction of proteins by the activity of protein modifying enzymes found naturally in milk [20] resistance to thermal transactions, which re-activity during the storage of cooled but less active in the 
transactions stored in the darkness, These results came in line with the results obtained by those[6] who observed the breakdown of protein and vitamins and the oxidation of milk fat when storing the samples in light.

\subsection{Fat content:}

Statistical analysis showed that the effects of storage on fat were significant $(\mathrm{p}<.05)$. The fat in all samples tended to decrease during the storage period (Table 1). Fat slightly decreased in light-protected treatment, compared to those light exposed package. Lipase enzyme hydrolyze fat in milk to release a large amount of free fatty acid and affect yogurt flavors [21]. Lipase increased the production of free fatty acids in milk from the exposure to light compared with the light-protected treatment Fat content on the zero-day for formulas T0 was (4.29667). On day 3, fat had decreased to 4.29000, 3.99333 in the formulas $\mathrm{T} 1$ and $\mathrm{T} 2$ respectively. The fat values decreased to (3.79667) and (1.89000) in formulas T9 and T10 respectively after 15 days. Fat was decreased by lipase enzymes, which lipolysis fat, thus liberating free fatty acids, in raw milk or in pasteurized products total lipase activity is sufficient to induce rapid hydrolysis of a large proportion of the fat [22]. Previous studies of lipid degradation in dairy products have found that degradation is due to the secretion and activity of high-temperature bacterial-resistant lipase enzymes rather than lipid degradation by natural lipase enzymes in milk [23].

Table1. Summary of statistical significance of chemical Analysis (Total Protein, Casein and Fat) for milk packaged in high-density polyethylene (HDPE) with different experimental levels (light exposed and light protected) compared with controls over 15 day at $3 \mathrm{C}^{\circ}$.

\begin{tabular}{|c|c|c|c|}
\hline Treatment & Total Protein \% & Casein \% & Fat $\%$ \\
\hline To & $\begin{array}{c}a \\
2.99667 \pm 0.00577\end{array}$ & $\begin{array}{c}a \\
2.58333 \pm 0.00577\end{array}$ & $\begin{array}{c}a \\
4.29667 \pm 0.00577\end{array}$ \\
\hline T1 & $\begin{array}{c}a \\
2.98667 \pm 0.00577\end{array}$ & $\begin{array}{c}a \\
2.57667 \pm 0.00577\end{array}$ & $\begin{array}{c}a \\
4.29000 \pm 0.01000\end{array}$ \\
\hline T2 & $\begin{array}{c}a \\
2.86333 \pm 0.00577\end{array}$ & $\begin{array}{c}c \\
2.39000 \pm 0.01000\end{array}$ & $\begin{array}{c}\mathrm{C} \\
\mathbf{3 . 9 9 3 3 3} \pm \mathbf{0 . 0 0 5 7 7}\end{array}$ \\
\hline T3 & $\begin{array}{c}a \\
2.98667 \pm 0.00577\end{array}$ & $\begin{array}{c}a \\
2.59000 \pm 0.01000\end{array}$ & $\begin{array}{c}a \\
4.29000 \pm 0.01000\end{array}$ \\
\hline T4 & $\begin{array}{c}a \\
2.82000 \pm 0.01000\end{array}$ & $\begin{array}{c}d \\
2.19000 \pm 0.01000\end{array}$ & $\begin{array}{c}\mathrm{e} \\
3.49667 \pm 0.00577\end{array}$ \\
\hline T5 & $\begin{array}{c}\mathrm{a} \\
2.97333 \pm 0.00577\end{array}$ & $\begin{array}{c}a \\
2.53667 \pm 0.00577\end{array}$ & $\begin{array}{c}b \\
4.20000 \pm 0.00000\end{array}$ \\
\hline T6 & $\begin{array}{c}\text { b } \\
1.57667 \pm 0.00577\end{array}$ & $\begin{array}{c}\mathrm{e} \\
1.77000 \pm 0.01000\end{array}$ & $\begin{array}{c}\mathrm{f} \\
3.19000 \pm 0.01000\end{array}$ \\
\hline T7 & $\begin{array}{c}a \\
2.96000 \pm 0.01000\end{array}$ & $\begin{array}{c}a \\
2.54000 \pm 0.01000\end{array}$ & $\begin{array}{c}c \\
4.00000 \pm 0.0000\end{array}$ \\
\hline T8 & $\begin{array}{c}c \\
1.36670 \pm 0.00577\end{array}$ & $\begin{array}{c}f \\
1.21000 \pm 0.01000\end{array}$ & $\begin{array}{c}\mathrm{g} \\
2.99333 \pm 0.00577\end{array}$ \\
\hline T9 & $\begin{array}{c}a \\
2.94333 \pm 0.00577\end{array}$ & $\begin{array}{c}b \\
2.49000 \pm 0.01000\end{array}$ & $\begin{array}{c}d \\
3.79667 \pm 0.00577\end{array}$ \\
\hline T10 & $\begin{array}{c}c \\
1.39000 \pm 0.01000\end{array}$ & $\begin{array}{c}g \\
1.16000 \pm 0.01000\end{array}$ & $\begin{array}{c}h \\
1.89000 \pm 0.01000\end{array}$ \\
\hline
\end{tabular}

Data are presented as the means \pm standard deviation, different letters within each column indicate significant differences $(\mathrm{p} \leq 0.05)$. 
3.3. Acid Degree value (ADV), Acid value (AV), and free fatty acid (FFA):

The acid degree values of the milk samples from day 0 to day 15 are summarized in Table 2 . ADV on day 0 at $3^{\circ} \mathrm{C}$ for $\mathrm{T} 0$, was 0.17000 , while $\mathrm{ADV}$ on day 3 at $3^{\circ} \mathrm{C}$ for $\mathrm{T} 1$, and $\mathrm{T} 2$ were 0.17000 and 1.71333 respectively. After day 15, acid degree value had increased to 0.29667 and 2.16000 in the samples $\mathrm{T} 9$ and $\mathrm{T} 10$ respectively. Lipolysis values were higher in milk from the exposure to light compared with the light-protected treatment. Elevation of acid degree values suggests degradation in the nutritional and sensory consistency of dairy products during storage [24]. These ADV findings suggest that storage time and temperature, and their interactions, have a major effect on the lipolysis of experimental goat's cheeses. The (AV) of all yogurt samples tended to increase during the storage period (Table 2). The $\mathrm{AV}$ values at 0 day at $3 \mathrm{C}^{\circ}$ for $\mathrm{T} 0$, were 0.04333 . After then acid value had increased in the samples. Free fatty acid (FFA) differences between the samples were significant $p<0.05$. The FFA of all formulas tended to increase during storage [Table2]. The free fatty acid content increases in milk during processing and storage[25]. In general, the increased ADV, AV, and FFA values were related to the increment of acidity in milk samples, which suggests the degradation of dairy sensory qualities during storage[26].

Table 2. Summary of statistical significance of Chemical Analysis (Acid Degree value, Acid value, and Free Fatty acid) for milk packaged in high-density polyethylene (HDPE) with different experimental levels (light exposed and light protected) compared with controls over 15 days at $3 \mathrm{C}^{\circ}$.

\begin{tabular}{|c|c|c|c|}
\hline Treatment & Free Fatty acid & Acid value & Acid Degree valu \\
\hline To & $\begin{array}{c}\mathrm{j} \\
0.01333 \pm 0.00577\end{array}$ & $\begin{array}{c}\mathrm{j} \\
0.04333 \pm 0.0057\end{array}$ & $\begin{array}{c}f \\
0.17000 \pm 0.01000\end{array}$ \\
\hline T1 & $\begin{array}{c}\mathbf{j} \\
0.02333 \pm 0.00577\end{array}$ & $\begin{array}{c}\text { i } \\
0.05333 \pm 0.00577\end{array}$ & $\begin{array}{c}f \\
0.17000 \pm 0.01000\end{array}$ \\
\hline T2 & $\begin{array}{c}\mathrm{e} \\
1.29667 \pm 0.01155\end{array}$ & $\begin{array}{c}\mathrm{K} \\
\mathbf{0 . 0 2 3 3 3} \pm \mathbf{0 . 0 0 5 7 7}\end{array}$ & $\begin{array}{c}b \\
1.71333 \pm 0.00577\end{array}$ \\
\hline T3 & $\begin{array}{c}\text { i } \\
0.04667 \pm 0.00577\end{array}$ & $\begin{array}{c}\text { h } \\
0.08333 \pm 0.00577\end{array}$ & $\begin{array}{c}\text { ef } \\
0.19000 \pm 0.01000\end{array}$ \\
\hline T4 & $\begin{array}{c}\mathrm{d} \\
1.57333 \pm 0.00577\end{array}$ & $\begin{array}{c}c \\
1.54000 \pm 0.01000\end{array}$ & $\begin{array}{c}d \\
1.15300 \pm 0.569\end{array}$ \\
\hline T5 & $\begin{array}{c}\text { h } \\
0.07667 \pm 0.00577\end{array}$ & $\begin{array}{c}g \\
0.42000 \pm 0.01000\end{array}$ & $\begin{array}{c}\mathrm{e} \\
0.22000 \pm 0.1000\end{array}$ \\
\hline T6 & $\begin{array}{c}c \\
2.79333 \pm 0.00577\end{array}$ & $\begin{array}{c}b \\
2.58000 \pm 0.01000\end{array}$ & $\begin{array}{c}c \\
1.58000 \pm 0.572\end{array}$ \\
\hline T7 & $\begin{array}{c}\mathrm{g} \\
0.09000 \pm 0.00000\end{array}$ & $\begin{array}{c}f \\
0.52000 \pm 0.01000\end{array}$ & $\begin{array}{c}\mathrm{e} \\
0.26000 \pm 0.01000\end{array}$ \\
\hline T8 & $\begin{array}{c}b \\
3.92000 \pm 0.01000\end{array}$ & $\begin{array}{c}d \\
0.82000 \pm 0.01000\end{array}$ & $\begin{array}{c}a \\
2.02000 \pm 0.01000\end{array}$ \\
\hline T9 & $\begin{array}{c}\text { f } \\
1.21333 \pm 0.00577\end{array}$ & $\begin{array}{c}\mathrm{e} \\
0.69667 \pm 0.01155\end{array}$ & $\begin{array}{c}\mathrm{e} \\
0.29667 \pm 0.01155\end{array}$ \\
\hline T10 & $\begin{array}{c}a \\
5.46667 \pm 0.00577\end{array}$ & $\begin{array}{c}a \\
2.92000 \pm 0.01000\end{array}$ & $\begin{array}{c}a \\
2.16000 \pm 0.01000\end{array}$ \\
\hline
\end{tabular}

Data are presented as the means \pm standard deviation, different letters within each column indicate significant differences ( $\mathrm{p} \leq 0.05)$. 


\section{Conclusions:}

The chemical studies shown Packaging of milk by foil overwrap assisted in obtaining extension storage of milk around about up to 15 days. Further, since there are several types of food whose quality is impaired when they are exposed to light can be used this knowledge to several types of food to protect from light.

\section{References}

[1] S. Sarkar, "S . Sarkar . UHT Processing Best Technology For Shelf -Life Extension of Milk UHT Processing - Best Technology For Shelf - Life Extension of Milk," no. January, 2020.

[2] J. A. Ansari, M. Ismail, and M. Farid, "Extension of shelf life of pasteurized trim milk using ultraviolet treatment," J. Food Saf., no. September 2019, pp. 1-9, 2020.

[3] J. B. Webster, S. E. Duncan, J. E. Marcy, and S. F. O'Keefe, "Controlling light oxidation flavor in milk by blocking riboflavin excitation wavelengths by interference," $J$. Food Sci., vol. 74, no. 9, 2009.

[4] S. Choudhary, B. Joshi, G. Pandey, and A. Joshi, "Application of single and dual fluorophore-based $\mathrm{pH}$ sensors for determination of milk quality and shelf life using a fibre optic spectrophotometer," Sensors Actuators, B Chem., vol. 298, no. June, p. 126925, 2019.

[5] C. Brothersen, D. J. McMahon, J. Legako, and S. Martini, "Comparison of milk oxidation by exposure to LED and fluorescent light," J. Dairy Sci., vol. 99, no. 4, 2016.

[6] F. Mestdagh, B. De Meulenaer, J. De Clippeleer, F. Devlieghere, and A. Huyghebaert, "Protective influence of several packaging materials on light oxidation of milk," J. Dairy Sci., vol. 88, no. 2, pp. 499-510, 2005.

[7] D. Airado-Rodríguez, N. Intawiwat, J. Skaret, and J. P. Wold, "Effect of naturally occurring tetrapyrroles on photooxidation in cow's milk," J. Agric. Food Chem., vol. 59, no. 8, pp. 3905-3914, 2011.

[8] J. P. Wold, J. Skaret, and T. K. Dalsgaard, "Assessment of the action spectrum for photooxidation in full fat bovine milk," Food Chem., vol. 179, pp. 68-75, 2015.

[9] H. L. Potts, K. N. Amin, and S. E. Duncan, "Retail lighting and packaging influence consumer acceptance of fluid milk," J. Dairy Sci., vol. 100, no. 1, pp. 146-156, 2017.

[10] M. Ščetar, I. Barukčić, M. Kurek, K. L. Jakopović, R. Božanić, and K. Galić, "Packaging perspective of milk and dairy products," Mljekarstvo, vol. 69, no. 1, pp. 320, 2019.

[11] J. P. Wold, J. Skaret, and T. K. Dalsgaard, "Assessment of the action spectrum for photooxidation in full fat bovine milk," Food Chem., vol. 179, no. 1, pp. 68-75, 2015.

[12] D. S. Johnson, S. E. Duncan, L. M. Bianchi, H. H. Chang, W. N. Eigel, and S. F. O'Keefe, "Packaging modifications for protecting flavor of extended-shelf-life milk from light," J. Dairy Sci., vol. 98, no. 4, pp. 2205-2214, 2015.

[13] M. Weston, R. P. Kuchel, M. Ciftci, C. Boyer, and R. Chandrawati, "A polydiacetylene-based colorimetric sensor as an active use-by date indicator for milk," $J$. Colloid Interface Sci., vol. 572, pp. 31-38, 2020.

[14] D. Airado-Rodríguez, I. Durán-Merás, T. Galeano-Díaz, and J. P. Wold, "Front-face fluorescence spectroscopy: A new tool for control in the wine industry," J. Food Compos. Anal., vol. 24, no. 2, pp. 257-264, 2011.

[15] M. H. Seo, S. Y. Lee, Y. H. Chang, and H. S. Kwak, "Physicochemical, microbial, and sensory properties of yogurt supplemented with nanopowdered chitosan during storage," J. Dairy Sci., vol. 92, no. 12, pp. 5907-5916, 2009.

[16] Töpel, "LABORATORY CATALOGUE for 
milk analysis," 2011.

[23]

[17] L. S. Castillo, G. W. Trimberger, C. R. Henderson, B. L. Herrington, and K. L. Turk, "Comparison of Orange G Dye, Formol Titration, and Kjeldahl Methods for Milk Protein Determinations," J. Dairy Sci., vol. 45, no. 9, pp. 1079-1082, 1962.

[18] Ş. Köse and E. Ocak, "Changes occurring in plain, straining and winter yoghurt during the storage periods," African J. Biotechnol., vol. 10, no. 9, pp. 1646-1650, 2011.

[19] K. Savijoki, H. Ingmer, and P. Varmanen, "Proteolytic systems of lactic acid bacteria," Appl. Microbiol. Biotechnol., vol. 71, no. 4, pp. 394-406, 2006.

[20] A. C. Alting, Cold gelation of globular proteins. 2003.

[21] S. Nsogning Dongmo, S. Procopio, B. Sacher, and T. Becker, "Flavor of lactic acid fermented malt based beverages: Current status and perspectives," Trends Food Sci. Technol., vol. 54, pp. 37-51, 2016.

[22] H. C. Deeth, "Lipoprotein lipase and lipolysis in milk," Int. Dairy J., vol. 16, no. 6, pp. 555-562, 2006.
H. C. Deeth, "The role of phospholipids in the stability of milk fat globules," Aust. J. Dairy Technol., vol. 52, no. 1, pp. 44-46, 1997.

[24] W. Nouira, Y. W. Park, Z. Guler, and T. Terrill, "Comparison of free fatty acid composition between low-fat and full-fat goat milk cheeses stored for 3 months under refrigeration," Open J. Anim. Sci., vol. 01, no. 02, pp. 17-24, 2011.

[25] B. M. Wherry, Y. Jo, and M. A. Drake, "Concentration of furfuryl alcohol in fluid milk, dried dairy ingredients, and cultured dairy products," J. Dairy Sci., vol. 102, no. 5, pp. 3868-3878, 2019.

[26] A. Siddique and Y. W. Park, "Evaluation of Correlation between Acid Degree Value and Peroxide Value in Lipolysis of Control and Iron Fortified Caprine Milk Cheeses during 4 Months Storage," Open J. Anim. Sci., vol. 09, no. 01, pp. 1-11, 2019. 